\title{
Marmara Island earthquakes, of 1265 and 1935; Turkey
}

\author{
Y. Altınok ${ }^{1}$ and B. Alpar ${ }^{2}$ \\ ${ }^{1}$ Istanbul University, Engineering Faculty, Department of Geophysics, 34850 Avcilar, Istanbul, Turkey \\ ${ }^{2}$ Istanbul University, Institute of Marine Sciences and Management, 34116 Vefa, Istanbul, Turkey
}

Received: 27 September 2006 - Revised: 23 November 2006 - Accepted: 23 November 2006 - Published: 30 November 2006

\begin{abstract}
The long-term seismicity of the Marmara Sea region in northwestern Turkey is relatively well-recorded. Some large and some of the smaller events are clearly associated with fault zones known to be seismically active, which have distinct morphological expressions and have generated damaging earthquakes before and later. Some less common and moderate size earthquakes have occurred in the vicinity of the Marmara Islands in the west Marmara Sea. This paper presents an extended summary of the most important earthquakes that have occurred in 1265 and 1935 and have since been known as the Marmara Island earthquakes. The informative data and the approaches used have therefore the potential of documenting earthquake ruptures of fault segments and may extend the records kept on earthquakes far before known history, rock falls and abnormal sea waves observed during these events, thus improving hazard evaluations and the fundamental understanding of the process of an earthquake.
\end{abstract}

\section{Introduction}

The North Anatolian Fault (NAF) is a major right-lateral transform fault controlling the westward motion of the Anatolian Plate. It has shown cyclical seismic behavior, with century-long cycles beginning in the east and progressing westward. The northern branch of the NAF system in the Marmara Sea region, where it splays into two major fault branches about $100 \mathrm{~km}$ apart, has a very distinct morphological expression and is seismically active (Fig. 1). Most of the lateral motion is transferred obliquely from the southern to the northern branch, across the Marmara basin. The tectonic regimes and different structural models, which have been put forward for the NAF in the Marmara Sea region by various researchers, were discussed in Yaltırak (2002) in detail. Recently, Provost et al. (2003) through a 3-D mechanical modeling of the GPS velocity field, provided an estimate of the NAF slip rate in the Marmara Sea in the order of $17.5 \mathrm{~mm} / \mathrm{yr}$.

Correspondence to: Y. Altınok

(yaltinok@istanbul.edu.tr)
Such a rate is very consistent with the long term slip rate estimates from geological reconstructions covering a period of 3-5 million years. Therefore, we may assume that the large earthquakes occurring along the NAF system and in the Marmara Sea region inherit a common systematic.

Apart from the systematic and large earthquakes, some others of moderate scale are known to have existed, possibly having occurred on other secondary faults, for example, on some diverse-sized strike-slip fault segments which take place along the southern margin of the Marmara Sea. Some of these occurred in and around the Marmara Islands which are located between the Kapıdağ Peninsula in the south and Şarköy in the SW margin of the Marmara Sea (Fig. 1). These earthquakes are classified as the Marmara Island earthquakes in this paper.

The Marmara Islands have always been on the nautical passageway between the countries of the Mediterranean and Black Sea. They are composed of three bigger (Marmara, Paalimanı, Ava) and many smaller islands (Ekinlik, Koyun, Hayırsız, Fener, Yer, Tavan and Mamalı). The Marmara Island, known as Proconnesus in classical times, is the biggest one with an area of $117 \mathrm{~km}^{2}$. Thirteen shipwrecks have been identified around the islands since 1993 (PAP/RAC, 2005).

Our research has shown us that these earthquakes have some common characteristics. They usually are of shallow epicenters, and their effects are generally restricted to the west Marmara Sea. There are not many details on the literature on these earthquakes but there were records of tumbling boulders from steep precipices and of others causing abnormally destructive sea waves. In this study, the Marmara island earthquakes occurred in 1265 and 1935; associated tectonic setting and sea waves will be under focus.

\section{Earthquakes in the region}

Throughout history, earthquakes have been the most damaging natural disasters that have affected the study area (Ambraseys and Finkel, 1995; Ambraseys, 2000, 2002a; Pinar et al., 2003). They were strong and caused damage particularly in small villages on the islands, from where we have little

Published by Copernicus GmbH on behalf of the European Geosciences Union. 


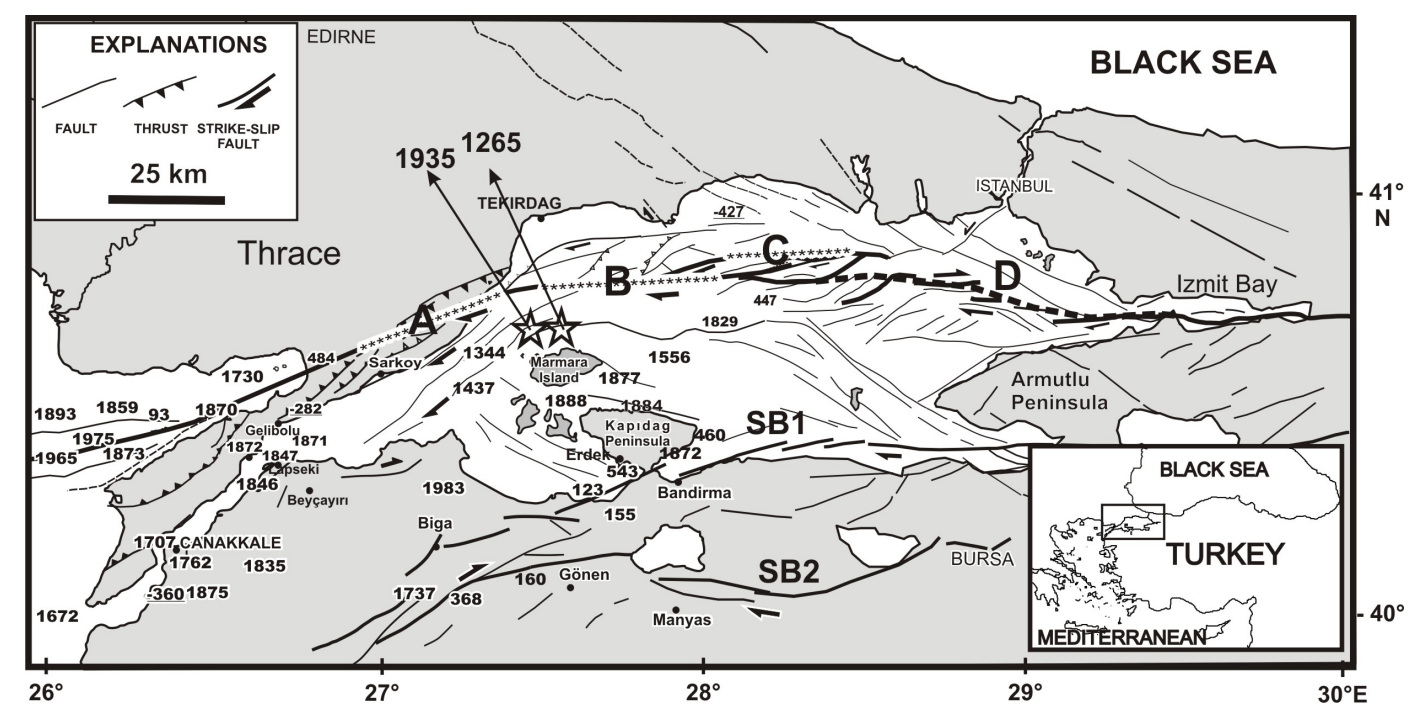

Fig. 1. Historical earthquakes (from 360 B.C. to present) of the Western Marmara Sea region (modified from Altınok et al., 2003). Marmara Island earthquakes are different from those occurred on the northern branch of the North Anatolian right-lateral strike-slip fault system (NAF) or on its Southern branches of SB1 and SB2. (A) 824, 1081 (?), 1354, 1659 1912; (B) 796, 1063, 1343, 1569, 1766-2; (C) 790, 1032, 1346, 1569, 1766-1 earthquakes. D (dashed line): probable rupture of the expected earthquake in the Marmara Sea.

information. Historical events (before 1900) are usually difficult to map out because their estimated epicenter locations usually coincide partially or wholly; therefore they are listed in Table 1.

Historical sources are rarely explicit enough to be definitive, especially for the Marmara Sea events with horizontal displacements on its strike slip faults. However, very little is known in detail about their effects in the rural areas of the Marmara Islands. It is therefore difficult to associate the earthquakes in Table 1 with a probable style of known Quaternary faulting.

Some important and well-documented data are as follows:

In 123, the flooding of the River Rhyndacus (Orhaneli River, a tributary of Kocasu River) is "prophesied"; "Cyzicus, dweller on the vine-clad Propontis, Rhyndacus shall dash his stream about thee in a swelling wave" (Guidoboni et al., 1994).

In 460, the city walls of Cyzicus in Kapıda $\breve{g}$ Peninsula were partly collapsed (Guidoboni et al., 1994). Cyzicus was established by Dolions. The name of the city was taken from legend of the Argonauts and from king Kyzikos.

In the 543 earthquake, most of the city walls of Erdek (Artaki) were demolished. Seismic sea waves were reported. By the end of the earthquake the townsfolk had abandoned the city.

The earthquakes of June 1042 and September 1064 that occurred in the western part of Istanbul made the greatest damage in Iznik and the Kapıdağ Peninsula (Skylitzes age; Skylitzes Cont.; Glykas age).

On 13 October 1877, only 8 survived in the Marmara village out of 94 houses and 34 houses were destroyed at Paal- imanı (Alonia) Island (Ambraseys, 2000). The shock was strong at Erdek and Çanakkale and was reported as being felt from Hisarlık, Ezine, Edirne and Istanbul. The tremors were followed by a few aftershocks.

The instrumental seismicity (1900-2006; ISC, NEIC, EMSC bulletins) shows a scatter of epicenters of moderate earthquakes around the northern branch of the NAF and on the NE margin of the Marmara Island (Fig. 2). The moment tensor solution of 22 events (Pınar et al., 2003), most of which took place following the 1999 Izmit earthquake $(\mathrm{Mw}=7.4)$, indicate normal faulting with oblique components stimulates most of the earthquakes to the north of the Marmara Islands, contrary to that of the main strike-slip fault in the north.

\subsection{Earthquake (10-12 August 1265)}

This event is known as Proconnesus earthquake, occurred at 11 August, 40.7 N, 27.4 E, h=n, M=(6.6) (Papazachos and Papazachou, 1997).

The historian G. Pakhymeres himself, felt the earthquake and reported it (Pakhymeres, p. 377). Along with a committee of four people, Pakhymeres goes to pay a visit to the exiled patriarch Arsenios (Patriarch of Istanbul, 1255-1267) in order to tell him the decision of the emperor and the synods (Pakhymeres, p. 353). The committee leaves Istanbul on 25 July 1265 and arrives in the Marmara Island two days later, staying there for 15 days (Pakhymeres, p. 373; Failler, 1981). After their visit to Arsenios, upon their return, a terrible storm breaks out. The committee seeks refuge in the bay of Galenolimenas, NW of the island (Pakhymeres, pp. 373375). In the middle of the night a strong earthquake occurs. 
Table 1. The moderate to large earthquakes occurred in the region of the Marmara Islands.

\begin{tabular}{|c|c|c|c|c|c|}
\hline No & Date & Lon Lat & Location & Intensity & Remarks \\
\hline 1 & 10 Oct 123 & & Erdek & & Tsunami ? \\
\hline 2 & 7 April 460 & $(40.40 \mathrm{~N} 27.90 \mathrm{E})$ & Erdek & $\begin{array}{l}\text { (VIII) } \\
\mathrm{M}=(6.3)\end{array}$ & \\
\hline 3 & 6 Sep 543 & $(40.35 \mathrm{~N} 27.80 \mathrm{E})$ & $\begin{array}{l}\text { Erdek, Bandırma } \\
\text { Kapıdağ Peninsula }\end{array}$ & $\begin{array}{l}\text { IX } \\
M=(6.6)\end{array}$ & Tsunami \\
\hline 4 & June 1042 & & Iznik, Erdek & & \\
\hline 5 & Sep 1064 & $(40.40 \mathrm{~N} 28.00 \mathrm{E})$ & Iznik, Erdek & IX & \\
\hline 6 & 10-12 Aug 1265 & $(40.70 \mathrm{~N} 27.40 \mathrm{E})$ & Marmara Islands & $M=(6.6)$ & Tsunami \\
\hline 7 & 10 May 1556 & $(40.30 \mathrm{~N} 28.00 \mathrm{E})$ & Edincik-Erdek & $\begin{array}{l}(\mathrm{IX}) \\
\mathrm{M}=(7.0)\end{array}$ & \\
\hline 8 & $\begin{array}{l}\text { 12/13 Jan } 1872 \\
10: 15\end{array}$ & $(40.40 \mathrm{~N} 27.80 \mathrm{E})$ & Erdek & $\begin{array}{l}\mathrm{VI} \\
\mathrm{M}=4.9\end{array}$ & \\
\hline 9 & 13 Oct 1877 & $\begin{array}{l}(40.60 \mathrm{~N} 27.60 \mathrm{E}) \\
(40.50 \mathrm{~N} 27.50 \mathrm{E})\end{array}$ & Marmara Islands & $\begin{array}{l}(\mathrm{VIII}) \quad \mathrm{M}_{s}=5.5 \\
\mathrm{M}=6.1\end{array}$ & \\
\hline 10 & $\begin{array}{l}1 \text { Nov } 1877 \\
08: 35\end{array}$ & $(40.60 \mathrm{~N} 27.60 \mathrm{E})$ & Marmara Islands & (VI) $\mathrm{M}=4.9$ & \\
\hline 11 & 13 May 1884 & $(40.40 \mathrm{~N} 27.80 \mathrm{E})$ & Bandırma, Erdek, Balıkesir & (VII) & \\
\hline 12 & 6 April 1888 & & Erdek, Pasalimanı & & \\
\hline 13 & 4 Jan 1935 & $(40.64 \mathrm{~N}, 27.51 \mathrm{E})$ & Marmara Islands & $\mathrm{M}_{s}=6.4$ & Tsunami \\
\hline
\end{tabular}

1 - Hasluck (1910); Doğancı (2001); This earthquake is dated 120/128 by Guidoboni et al. (1994). 2 - Ambraseys and Finkel (1991); Kılıç (2001); Guidoboni et al. (1994); Papazachos and Papazachou (1997). 3 - Malalas age; Soysal et al. (1981); Demirkent (2001); Ambraseys (2000); Guidoboni et al. (1994). 4 - Skylitzes age p. II, p. 532; Demirkent (2001). 5 - Demirkent (2001); Skylitzes Cont., p. 657; Glykas, age p. 605. 6 - Papazachos and Papazachou (1997); Ozansoy (2001); Ambraseys (2002). 7 - Ambraseys and Finkel (1995). 8 - Öcal (1968); Soysal et al. (1981). 9 - Soysal et al. (1981); Ambraseys (2000); Öcal (1968). 10 - Basiret (25 November 1877). 11 - Öcal (1968); Basiret (9 November 1877); Soysal et al. (1981). 12 - BOA Y.PRK.ASK. 54/16. 13 - Ambraseys (1988).

Upon its impact, a big piece of the mountain breaks off and tumbles into the sea, creating huge waves that hit the shore and swallow up the area. The committee members are terrified (Pakhymeres, p. 374-377).

The date of this earthquake is not clear. It might have happened between 10-12 August because the committee had a terrible trip back and were able to reach Istanbul on the 16th. All of this was interpreted as the result of not having had the Patriarch's blessing (Pakhymeres, p. 377).

There is no quantitative element about the earthquake. The high intensity of the earthquake implies that the epicenter should be very close to the hard metamorphic rocks that form the mountain ranges of Marmara Island, possibly even underwater (Ozansoy, 2001).

Some small sea waves were reported by eyewitnesses on Marmara Island. Ambraseys (2002b) believes that it was not of seismic origin, but was caused by the collapse of a rock mass from a mountain near Çınarlı. He defines the sea waves as spurious events. Even some false events can usually be assigned to historical earthquakes when they only consisted on storms, the sea waves occurred in this specific event are believed different from the storm waves occurred in the same period, as huge waves created were accompanied with the mountain break-off.
2.21935 Earthquake (16:41:29 local time, 4 January 1935)

This event is known as Erdek (Cyzicus) and Marmara Islands earthquake, occurred at 14:41:29, $40.64 \mathrm{~N}, 27.51 \mathrm{E}$ (ISS), $\mathrm{h}=0-60 \mathrm{~km}(\mathrm{SEAP}), \mathrm{M}_{s}=6.4, \mathrm{I}_{o}=\mathrm{IX}$ (MSK) (Ambraseys, 1988).

Along with these heavily damaging earthquakes in the Marmara Islands and Erdek, three violent aftershocks also occurred (Pinar and Lahn, 1952). The quake was strongly felt also in Istanbul, Tekirdağ, Edirne, Izmir and Bursa (Cumhuriyet, 5 January 1935; Ulus, 5 January 1935). The villages of Gündoğdu, Çınarlı and Asmalı on Marmara Island were totally, and the center of the island was partially destroyed. In total, 922 houses were destroyed, along with 128 houses in the village of Türkeli on Avşa Island (Afisia), the whole villages of Asmalı and Yiğitler (Azaplar or Araplar), 100 houses in Gündoğdu, and 30 houses in Ekinlik (or Kutali) Island (Akşam, 9 January 1935; Kurun, 11 January 1935). As the earthquake took place during the day, there were not many human casualties except 5 dead and 30 people wounded. The largest aftershocks occurred within $2 \mathrm{~h}$ at 15:18:57 $\left(\mathrm{M}_{s}=4.6\right), 15: 19: 24\left(\mathrm{M}_{s}=4.5\right)$ and 16:20:05 $\left(\mathrm{M}_{s}=6.3\right)$ and continued until 7 March 1935 (Ayhan et al., 2000). 


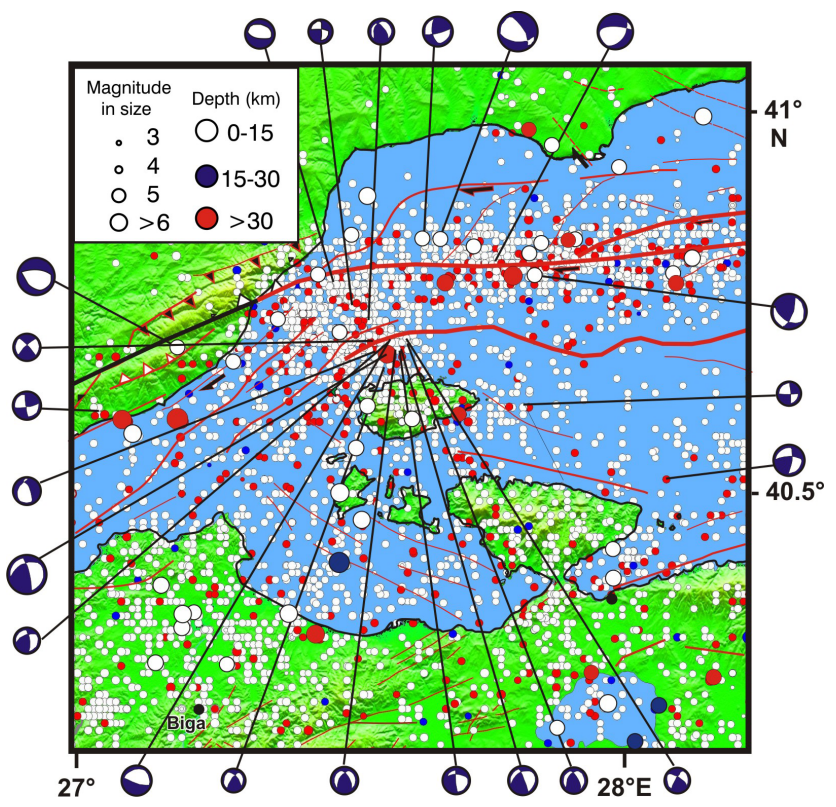

Fig. 2. Instrumental earthquakes occurred between 1900 and June 2006. Data is provided from the catalogues of Kandilli Observatory (KOERI). Geographic distribution of the 22 individual focal mechanism solutions obtained from Pinar et al. (2003) was superimposed. Circle size represents the magnitude of the earthquake, and ranges from 0 to 6.8. Figure was drawn using the GMT software (Wessel and Smith, 1998).

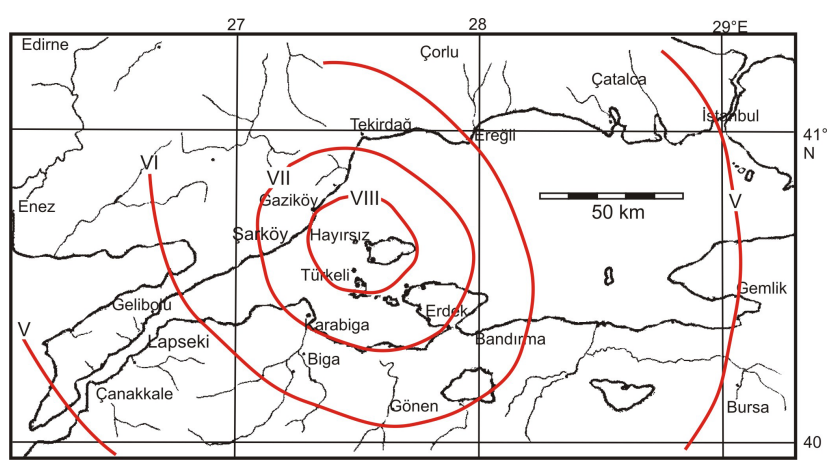

Fig. 3. Isoseismal map of the 1935 Marmara Island Earthquake (Ambraseys, 1988).

As the villages of Poyrazlar and Harmanlı on Paalimanı Island were totally destroyed, the villages of Çınarlı, Paalimanı and Balıklı took heavy damage. All wells dried up and landslides were reported on Marmara Island (Akşam, 9 January 1935). The maximum intensity of IX (MSK) was assigned by Ambraseys (1988) (Fig. 3).

The public rumor is that Hayırsı Island (Gaidaura), west of Marmara Island, was literally divided into two parts from the middle. This is an interesting point and reflects the earthquake's intensity. More realistically, the fog horn building on top of the island was demolished and the cape part of the

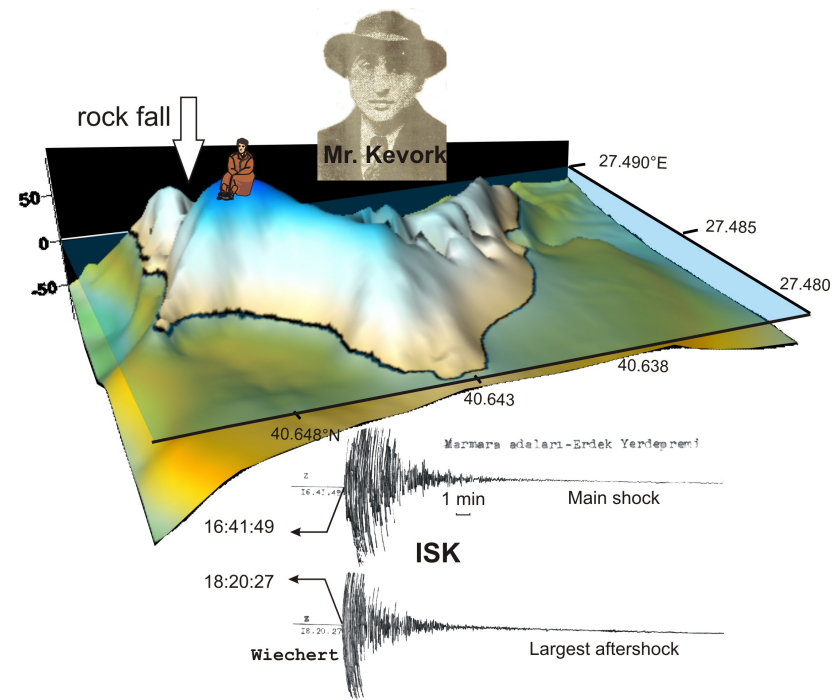

Fig. 4. Morphologic and bathymetric appearance supports extensive submergence along the northern margin of the Hayırsiz Island during the 1935 event, as witnessed by Mr. Kevork. The data based upon the ISK (Istanbul) Wiechert seismograms are from "Legancy Data Rescue Project” (No: 05T204), Boğaziçi University.

island broke off and fell into the sea (Son Posta, 11 January 1935). The rocks at shore had fallen into the sea, three sides of the island were submerged and the sea had risen (Milliyet, 12 January 1935). A crack as long as $4 \mathrm{~m}$ had opened in front of the light house (Akşam, 17 January 1935). However, the telephone cable crossing the Marmara Sea, was still working.

Loud noises from underground were heard and the fountains at Narlı and Ocaklar villages on the Kapıdağ Peninsula and on Ava Island dried up. Sudden decreases of the groundwater levels were observed in some wells placed along the Dardanelles strait (e.g. Lapseki and Beyçayırı village) and fountains went dry (Son Posta, 20 January 1935). Such events should be related with some shallow deformations prior to and after the earthquake.

In the words of Mr. Kevork (Fig. 4): "We were constructing a big foghorn for the lifeboat service at Hayırsiz Island, right across Marmara Island. We had already placed the concrete foundations on top of the marble grounding and had almost completed the building up to its roof. We were to finish it up in a day or two. On Friday 4:45 (local time), the first tremors came. We were in the building then. The tremors lasted for 2 minutes. 15 minutes later a second, half an hour later, a third set of tremors followed. When the third came, I was outside, trying to gauge the damage done to the building. Suddenly I saw the ground move to and fro. I immediately sat down. Although from where I was sitting, normally the sea is not visible, somehow, I don't know how, I was able to see the sea. It was during this last tremor, when the whole building just collapsed." (Kurun, 10 January 1935). 


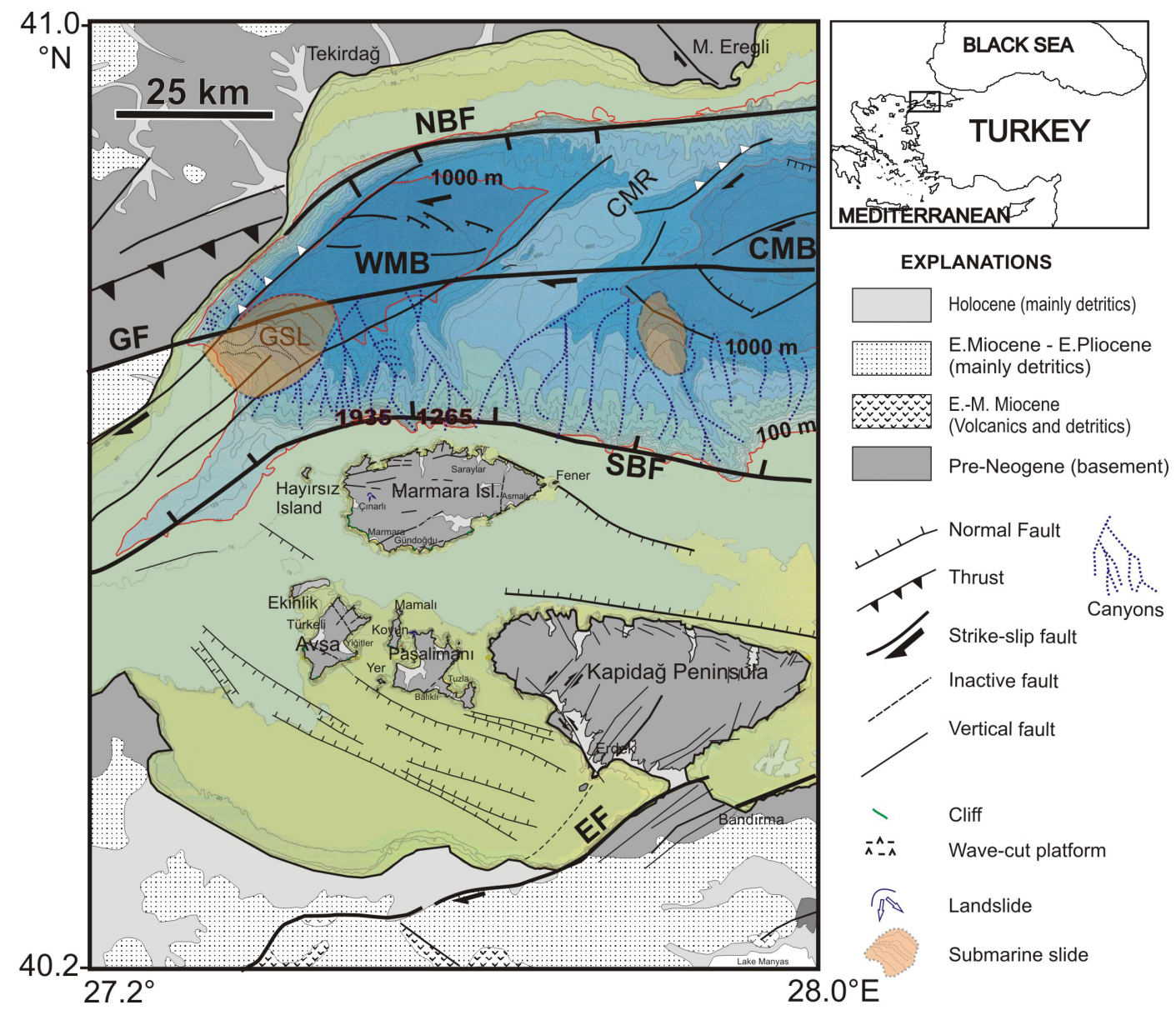

Fig. 5. Map showing the general tectonic features of the region of Marmara Islands such as simplified geology, active structures, submarine canyons and landslides. Compiled from Erentöz and Pamir (1964); Aksoy (1995); Yaltırak (2002); Yanmaz (2004); Karacık et al. (2004). WMB: Western Marmara (Tekirdağ) Basin, CMB: Central Marmara Basin, CMR: Central Marmara Ridge, GF: Ganos Fault, EF: Edincik Fault, SBF: Southern Boundary Fault, NBF: Northern Boundary fault of Northern Anatolian fault (NAF), GSL: Ganos Submarine Landslide.

The findings imply that the epicenter was located along the narrow northern shelf of the Marmara Island where faults with large normal components are dominant (Smith et al., 1995). Even no focal mechanism solutions are available, the isoseists which are almost circular between Gelibolu and Ereğli (Fig. 3) support normal-faulting mechanism in the northern margin of the Marmara Island. The earthquake caused rocks fall into the sea and three sides of the island were submerged. It is possible that the event may have produced some sea waves in and around Marmara Islands.

\section{Discussion of the earthquake generating faults}

The epicenters of the 1265 and 1935 earthquakes are not placed on the main fault zones in the Marmara Sea, e.g. Ganos fault zone or on the southern branch of NAF extending along the southern coast, but they occurred in the vicinity of the Marmara islands between these two main tectonic elements.
In geological and geomorphological sense, the Marmara islands are northward continuations of the Kapidağ Peninsula (Fig. 5), on which Palaeozoic metamorphic schist and younger magmatic rocks are dominant (Aksoy, 1995). As joined to the mainland by a tombolo, this dome-shaped peninsula displays $\mathrm{N}-\mathrm{S}$ oriented deep valleys and parallel mountain ridges as high as $800 \mathrm{~m}$, and forming steep slopes along its northern and western shores. The northern shores are especially very indented. Quaternary alluvial plains, mainly made up of sand and gravel deposits with clay intercalations, are distributed along the short valleys in the north and southwest coasts. Similarly pre-Permian metamorphic units are widely distributed on the Marmara Island (Erentöz and Pamir, 1964). The granodioritic intrusions, however, form an E-W trending steep topography in the central part of the island which rose to prominence in the Roman period and retained its importance in the Byzantine and Ottoman periods. Its quarries supplied marble carried by ships for extravagant imperial building programs (Tunçdilek, 1987). 


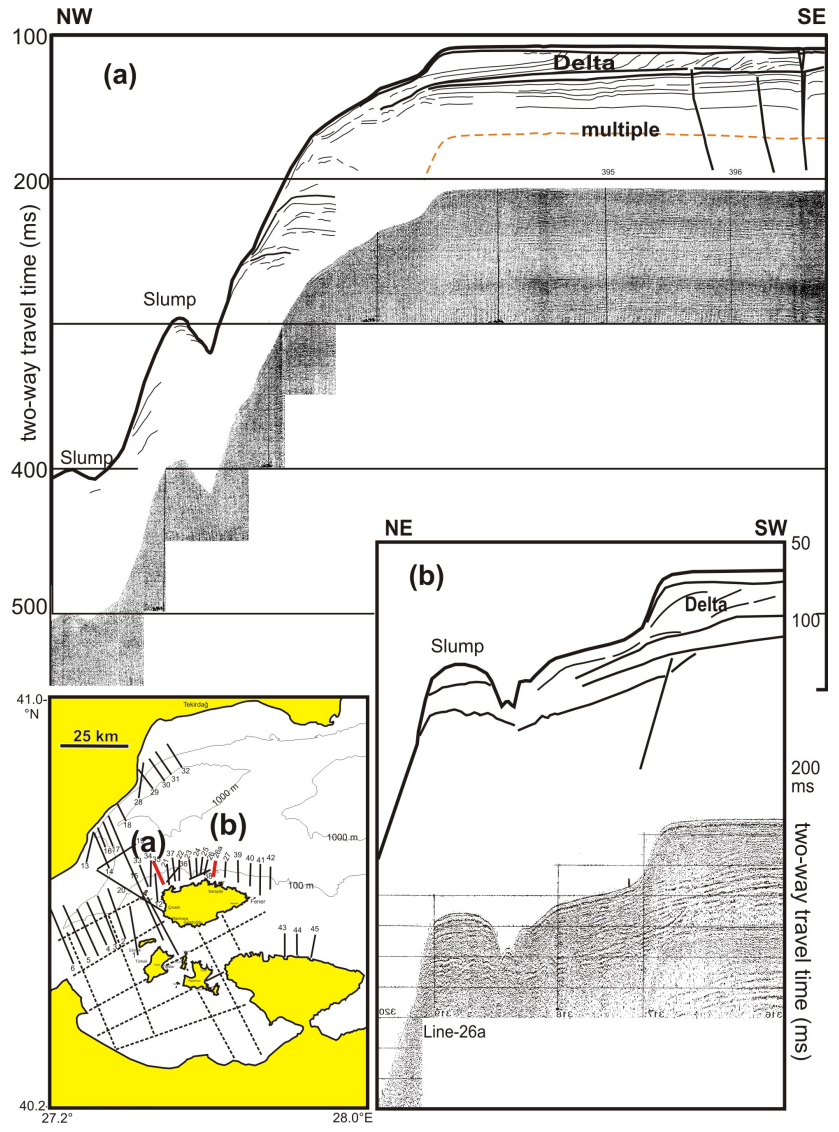

Fig. 6. Slumps at various depths can be seen off the shelf break to the north of the Marmara Islands.

The metamorphic and magmatic complexes observed on the Kapıdağ Peninsula and Marmara islands were bounded by tectonic elements in the north and south. The most important faults in the region are the NE-SW trended Edincik fault (northernmost rupture of the Bandırma-Gönen bend system), and other underwater faults bordering the Kapıdağ peninsula and Marmara Island in the north (Fig. 1) (Yaltırak, 2002; Karacik et al., 2004). In order to document the processes associated with underwater ruptures (homogenites, mass wasting, liquefaction, fluid seepages); high-resolution shallow (Beller, 1994; Domaç, 1994; Smith et al., 1995; Altınok et al., 2003) and multichannel seismic data (Smith et al., 1995; Adatepe et al., 2002; Ateş et al., 2003; Parke et al., 2003) were combined and reinterpreted (Fig. 5). A modified structural map was superimposed on the bathymetry map (1:250 000) compiled by Yanmaz (2004). The depth contours were produced from a data grid of 25 to $50 \mathrm{~m}$ intervals obtained from (a) regular investigations of the Marine Research Division by R/V MTA Sismik-1 from 1995 to 2003 using Atlas Deso echo-sounder and Seisnet Integrated Navigation Systems (DGPS), (b) multibeam data collected by Department of Navigation, Hydrography and Oceanography (SHODB), (c) the data of projects Marmara-2000 (R/V Le

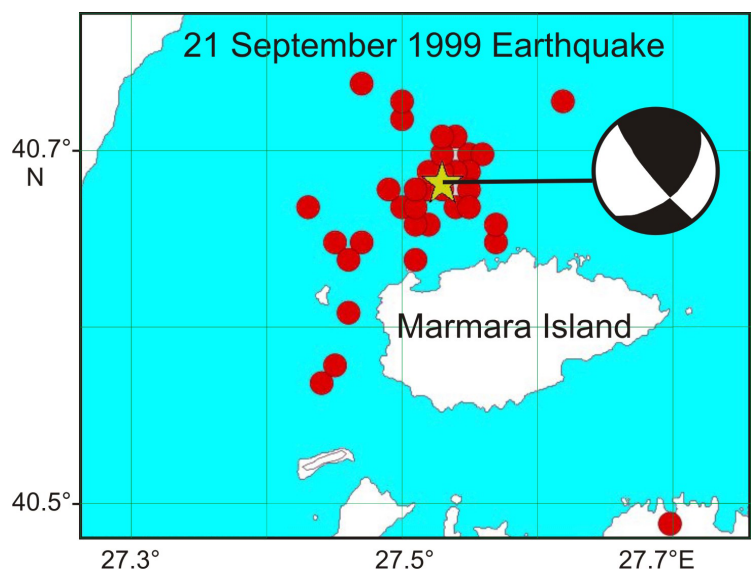

Fig. 7. Focal mechanism solution of the 21 September 1999 earthquake and its aftershock distribution (data from KOERI).

Suroit and R/V Odin Finder) and Marmara-2001 (R/V Urania). The data gaps especially for near shore areas were supplemented by the navigation charts of SHODB.

Seismic data reveal that the metamorphic core of the Marmara Island is uplifted as a footwall in the south of the southern boundary normal fault (Ateş et al., 2003) EW extending in the Marmara Sea. To the north of this fault, syn-tectonic growth strata submerge along this fault as a hanging wall. Positive Bouguer gravity anomalies over the Marmara Island and Kapıdağ Peninsula, contrary to negative anomalies over the deep Marmara troughs, are due to intrusions of the highdensity upper mantle (Adatepe et al., 2002), and this supports the uplift of the Marmara Island which is made up of felsic (igneous) rocks.

The seismic sparker data collected by Smith et al. (1995) on the northern shelf of the Marmara Island and south of the western Marmara basin show clear offsets in the buried sediments (Fig. 6). The siliciclastic mud deposits, with parallel reflections forming a 5-6 $\mathrm{m}$ thick drape over the delta progradation, are dominant around the shelves of the Marmara Islands. As inferred from the ${ }^{14} \mathrm{C}$ dating, the sedimentation rate is estimated $40-45 \mathrm{~cm} / 1000$ years (Çağatay et al., 1996). Sand and gravel-rich sediments are locally exposed near the coastal areas.

The Marmara Sea presents an interesting setting for landslide tsunamis. In the present-day seafloor setting along the northern slope of the Marmara islands, sedimentary bodies from submarine landslides are abundant at various depths in front of the progressive delta deposits. We interpret these features as morphological records of repeated slope failures and slump generated massive debris flows which may help to document syn-sedimentary tectonic movements. The sediments, however, are highly deformed, possibly due to the deformation associated with the tectonic regime. This area is defined as a zone of intense deformation by Parke et al. (2002). On 21 September 1999 a Mw 5.3 earthquake 
(KOERI: $40.69^{\circ} \mathrm{N} 27.58^{\circ} \mathrm{E}$, local time 00:27:59, $\mathrm{M}_{d}$ 5.0, $16.4 \mathrm{~km}$ deep; USGS: $\mathrm{M}_{b} 4.5$ ) occurred close to Marmara Island. Although the location of the earthquake may be within a 10-km-error range, in the absence of a reliable local seismic monitoring network in the region at that time, the epicenters of the main and following aftershocks were located near the western tip of the Marmara Island fault, suggesting this as a likely source (Fig. 7).

Zitter et al. (2006) defines some deep canyons in the southern Marmara slope off the Marmara Island. These canyons are organized in a network with large spaces between them and might be closely associated with previously active mass movements and underwater slides from the canyons' walls (Fig. 5). Frequent earthquake activity in the region sheds sediments from the flanks and contributes sediment on to the basin floor. At the southwestern margin of the Western Marmara Basin, a rough and hummocky topography can be observed over an oval area more than $75 \mathrm{~km}^{2}$ and several imbricated scars on it indicate multiple events of underwater failures.

\section{Conclusions}

Earthquakes in the Marmara Island region have some common characteristics. They are usually shallow earthquakes whose effects are generally restricted to the west Marmara Sea. Narrow and steep-sloped rock cliffs with small pockets of sediment which occur sporadically within indentations along the coast are dominant along the northern margin of the Marmara islands. Tumbling boulders detached from these steep precipices have been observed and reported. Abnormal sea waves have also been observed.

It is presumed that these earthquakes were triggered by the fault line running north of the Marmara Island. During the 1265 earthquake, the mountain in the region of Çınarl village, west of Marmara Island toppled into the sea after the violent tremors. In 1935, a similar event took place on Hayırsız Island. This sort of phenomena takes place on shores that are by nature rocky or with steep precipices, caught between beach-type sandy areas. Hayırsız and Marmara Island, with coasts that have a strong foundation, precipices looming in the foreground and rocky debris on the coastline may be evidence left behind by these earthquakes.

During the 1265 and 1935 earthquakes, sea waves were created in and around Marmara Island. The place where Mr. Kevork sat was approximately $100 \mathrm{~m}$ above sea level. From this position, he was able to see the sea momentarily, which was normally invisible. However, there are no records that indicate any effect these sea waves have had on the Marmara Island coastline. No slide or slump-like structures were observed on the seismic sections recorded on the shelf zones. In addition, the slump structures observed on the slopes beyond the shelf edge do not appear to be related to the earthquakes of 1265 and 1935, since their tsunami would have been mod- erately high and observed by many witnesses living along many coastal cities of the Marmara Sea. The results indicate that the sea waves observed during the Marmara Island earthquakes were caused by the massive boulders that tumbled into the sea, or the collapsing of Hayırsiz Island on three sides. The generated sea waves should be local and hardly noticeable from populated places at the northern or southern coasts of the Marmara Sea.

Acknowledgements. Funding was partly allocated by the research fund of the Istanbul University; under project UDP-680/08022006, and European project FP6-037058, Transfer. The authors thank N. Özer, N. Özel and C. Yaltırak for providing recent and historical earthquake data and seismic profiles.

Edited by: E. Pelinovsky

Reviewed by: two referees

\section{References}

Adatepe, F., Demirel, S., and Alpar, B.: Tectonic setting of the southern Marmara Sea region: based on seismic reflection data and gravity modelling, Marine Geology, 190, 383-395, 2002.

Aksoy, R.: Stratigraphy of the Marmara Island and Kapıdağ Peninsula, Bulletin of Turkish Petroleum Geologists Society, (in Turkish), 7(1), 33-49, 1995.

Altınok, Y., Alpar, B., and Yaltırak, C.: Şarköy-Mürefte 1912 Earthquake's Tsunami, Extension of the Associated Faulting in the Marmara Sea, Turkey, J. Seismol., 7(3), 329-346, 2003.

Ambraseys, N. N.: Engineering Seismology, J. Earthquake Eng. Structural Dynamics, 17, 1-105, 1988.

Ambraseys, N. N.: The seismicity of the Marmara Sea area 18001899, J. Earthquake Eng., 4(3), 377-401, 2000.

Ambraseys, N. N.: The seismic activity of the Marmara Sea region over the last 2000 years, Bull. Seismol. Soc. Amer., 92(1), 1-18, 2002a.

Ambraseys, N. N.: Seismic sea-waves in the Marmara Sea region during the last 20 centuries, J. Seismol., 6, 571-578, $2002 \mathrm{~b}$.

Ambraseys, N. N. and Finkel, C. F.: Long-term seismicity of Istanbul and the Marmara Sea region, Terra Nova, 3, 527-539, 1991.

Ambraseys, N. N. and Finkel, C.: The Seismicity of Turkey and Adjacent Areas 1500-1800, Eren Publishers, Istanbul, 1995.

Ateş, A., Kayıran, T., and Sincer, I.: Structural interpretation of the Marmara region, NW Turkey, from aeromagnetic, seismic and gravity data, Tectonophysics, 367, 41-99, 2003.

Ayhan, E., Alsan, E., Sancaklı, N., and Üçer, S. B.: Türkiye ve Dolayları Deprem Kataloğu / 1881-1980, Boğaziçi Üniversitesi Yayınevi, ISBN: 978975518984X, 126 p, 2000.

Beller, B.: Interpretation of shallow seismic data from western Marmara Island, unpublished diploma thesis, 471-L-1994-590.444, Istanbul Technical University, Istanbul, 1994.

Çağatay, N., Algan, O., Balkıs, N., and Balkıs, B.: Distribution of carbonate and organic carbon contents in Late Quaternary sediments of the southern Marmara shelf, Turkish J. Mar. Sci., 2, 67-83, 1996.

Demirkent, I.: Bizans kaynaklarına göre IV-XI yüzyıllarda Istanbul ve çevresinde depremler, in: Tarih Boyunca Anadoluda Doğal Afetler ve Deprem Semineri, edited by: Şahin, I., 22-23 May 2000, Globus Dünya Basımevi, Istanbul, pp. 51-65, 2001. 
Doğanc1, K.: Earthquakes affected Bursa and vicinity until $4^{t h}$ century (Bursa ve civarını etkileyen depremler - M.S. 4. yüzyıla kadar), in: Bursa Yöresinin Depremselliği ve Deprem tarihi, edited by: Abac1, N., Uludağ University, Bursa, pp. 61-66, 2001.

Domaç, H. G.: Interpretation of shallow seismic data from northwestern Marmara Island, unpublished diploma thesis, 511-L1994, Istanbul Technical University, Istanbul, 1994.

Erentöz, C. and Pamir, H. N.: 1/2,000,000 Geological Map of Turkey, Mineral Research and Exploration Institute of Turkey, Ankara, 1964.

Failler, A.: Choronologie at composition dans l'historie fr Georges Pachymèr, REB 39, 145-249, 1981.

Glykas age: Michaelis Glycae annales, Corpus Scriptorum Historiae Byzantinae, p. 605, edited by: Bekker, I., Bonn, 1836.

Guidoboni, E., Comastri, A., and Traina, G.: Catalogue of ancient earthquakes in the Mediterranean area up to the 10th century, pub. Istit. Nazion. Geofisica, Rome, 1994.

Hasluck, F. W.: Cyzicus, Cambridge University Press, Cambridge, UK, 1910.

Karacık, Z., Yılmaz, Y., and Pearce, J. A.: Petrological and geochemical characteristics of the Kapıdağ Peninsula and surrounding region, south Marmara Sea, Turkey, Proceedings of International Symposium on Earth System Sciences, Istanbul - Turkey, 8-10 September, 721-728, 2004.

Kılıç, Ş.: Byzantium earthquakes in and around Bursa between 5 and 15th centuries (5-15. yüzyıl Bursa ve çevresi Bizans dönemi depremleri), in: Bursa Yöresinin Depremselliği ve Deprem Tarihi, edited by: Abac1, N., Uludağ University, Bursa, pp. 67-70, 2001.

KOERI catalogue: http://www.koeri.boun.edu.tr, May 2006.

Malalas age: Ioannis Malalae Choronographia, Corpus Scriptorum Historiae Byzantinae, p. 482, edited by: Dindorf, L., Bonn, 1831.

Ozansoy, E.: Istanbul earthquakes 1200-1453 based on the Byzantium sources (Bizans kaynaklarına göre 1200-1453 Istanbul depremleri), in: Tarih Boyunca Anadolu'da Dogal Afetler ve Deprem Semineri, edited by: Şahin, I., 22-23 May 2000, Globus Dünya Presshouse, Istanbul, pp. 1-29, 2001.

Öcal, N.: Seismicity of Turkey and Earthquake Geography (Türkiye' nin Sismisitesi ve Zelzele Cografyası), Istanbul Kandili Rasathanesi, Publ. 8, 119 pp., Istanbul, 1968.

Pakhymeres, G.: Relations historiques, Corpus Fontium Historiae Byzantinae, edited by: Failler, A., t. 1, livres I-III, t. 2, livres IVVI, Paris 1984, T. 2, Corpus Scriptorum Historiae Byzantinae, edited by: Niebuhr, B., Bonnae, 1835.

PAP/RAC: Coastal Area Management in Turkey, Priority Actions Programme Regional Activity Centre, ISBN 953-6429-54-3, Split, Croatia, 2005.

Papazachos, B. and Papazachou, C.: The earthquakes of Greece, Editions Ziti Publ. Co., Thessaloniki-Greece, 356 pp, 1997.

Parke, J. R., White, R. S., McKenzie, D., Minshull, T. A., Bull, J., Kusçu, I., Görür, N., and Şengör, A. M. C.: Interaction between faulting and sedimentation in the Sea of Marmara, western Turkey, J. Geophys. Res., 107(B11), 2286, doi:10.1029/2001JB000450, 2002.

Parke, J. R., White, R. S., McKenzie, D., Minshull, T. A., Bull, J., Kuşçu, I., Görür, N., and Şengör, A. M. C.: MARM, Marmara Sea Reflection Profile. The Sea of Marmara - a 2-D Seismic Reflection Profile Data Archive, Data Set 03-001, Incorporated Research Institutions for Seismology, Data Management Center,
1408 NE 45th Street, Suite 201, Seattle, Washington 98105 USA, 2003.

Pınar, N. and Lahn, E.: Explanatory Catalogue for Turkish Earthquakes, (Türkiye Depremleri Izahlı Kataloğu), Bayındırlık ve Iskan Bakanlı̆̆ı, Imar Reisliği Yayınları, Seri 6, Sayı 36, 1952.

Pınar, A., Kuge, K., and Honkura, Y.: Moment tensor inversion of recent small to moderate sized earthquakes: implications for seismic hazard and active tectonics beneath the Sea of Marmara, Geophys. J. Int., 153, 133-145, 2003.

Provost, A. S., Chery, J., and Hassani, R.: 3D mechanical modeling of the GPS velocity field along the North Anatolian fault, Earth Planet. Sci. Lett., 209, 361-377, 2003.

Skylitzes age: Georgius Cedrenus Ionnasis Scylitzae ope, I-II, edited by: Bekker, I., p. 532, Bonn, 1839.

Skylitzes Cont.: Georgius Cedrenus Ionnasis Scylitzae ope, I-II, edited by: Bekker, I., p. 657, Bonn, 1839.

Smith, A. D., Taymaz, T., Oktay, F., Yüce, H., Alpar, B., Başaran, H., Jackson, J. A., Kara, S., and Şimşek, M.: High-resolution seismic profiling in the Sea of Marmara (Northwest Turkey): Late Quaternary sedimentation and sea-level changes, Geology Society of America Bulletin, 107, 923-936, 1995.

Soysal, H., Sipahioğlu, S., Kolçak, D., and Altınok, Y.: Türkiye ve Cevresinin Tarihsel Deprem Katalogu (M.O. 2100-M.S. 1900), TUBITAK, Project Number TBAG 341, Istanbul, 1981.

Tunçdilek, N.: Marmara Islands, Publication of Istanbul University, No. 3471, 146p, Istanbul (in Turkish), 1987.

Wessel, P. and Smith, W. H. F.: New, improved version of generic mapping tools released, EOS Trans. AGU 79(47), 579, 1998.

Yaltırak, C.: Tectonic evolution of the Marmara Sea and its surroundings, Mar. Geol., 190, 493-529, 2002.

Yanmaz, M.: Bathymetric chart of the Sea of Marmara. Scale 1:250,000. General Directorate of Mineral Research and Exploration, 06520 Ankara, 2004.

Zitter, T., Henry, P., and Özeren, M. S.: Slope instability in the Sea of Marmara and relationship with active faulting, in: International Workshop on Comparative Studies of the North Anatolian Fault (Northwest Turkey) and the San Andreas Fault (Southern California), edited by: Yaltırak, C., Istanbul Technical University, 14-18 August 2006, 94-95, 2006.

The General Directorate of the State (Ottoman) Archives, Turkish Republic Prime Ministry:

BBOA Y.PRK.ASK. 54/16, document dated 7 April 1888.

Consulted newspapers collections:

Akşam, 9 January 1935.

Akşam, 17 January 1935.

Basiret, 9 November 1877.

Basiret, 25 November 1877.

Cumhuriyet, 5 January 1935.

Kurun, 10 January 1935.

Kurun, 11 January 1935.

Milliyet, 12 January 1935.

Son Posta, 11 January 1935.

Son Posta, 20 January 1935.

Ulus, 5 January 1935. 